\title{
Cissus Populnea Flour Addition and Proximate Composition, Functional and Sedimentation Properties of Millet Kunu
}

\author{
Iombor TT $^{1 *}$, Yaaya $\mathbf{A A}^{2}$ \\ ${ }_{1,2}$ Department of Home Science and Management, University of Agriculture, PMB 2373, Makurdi, Benue State, Nigeria
}

Received: 28 December, 2018; Accepted: 28 February, 2019; Published: 15 March, 2019

*Corresponding author: Iombor TT, Department of Home Science and Management, University of Agriculture, PMB 2373, Makurdi, Benue State, Nigeria, Tel: +2348057418735, E-mail: theophilus0707@gmail.com

\begin{abstract}
The study evaluated the possibility of using cissus populnea mucilage flour as a colloid in beverage production and its influence on proximate composition, functional properties and sedimentation rate of millet kunu during storage at ambient temperature. Hot water (80 $-90{ }^{\circ} \mathrm{C}$ ) extraction method was used to extract the mucilage from fresh stem cuttings of cissus populnea plant. Freeze $\left(100 \mathrm{~g},-40^{\circ} \mathrm{C}, 48 \mathrm{hr}\right)$ drying method was used in mucilage flour production. Standard methods were used in millet-cissus kunu production and determination of the proximate composition, functional properties and sedimentation rates of the beverage samples. Results showed that addition of freeze dried cissus populnea mucilage flour to millet kunu significantly decreased its moisture content but increased its protein, fat, fibre, ash and carbohydrate contents, when compared to $100 \%$ millet kunu (control). Similarly, the addition of freeze dried cissus populnea mucilage flour to millet kunu significantly elevated the viscosity, $\mathrm{pH}$, and tritratable acidity of the beverage samples when compared to control. The addition of $C$. populnea mucilage flour to millet kunu equally reduced the rate of dissociation of the starch granules from the beverage during $8 \mathrm{hr}$ storage at ambient temperature. Freeze dried C. populnea mucilage flour has the potentials of serving as a colloid in beverages and improving its nutritional and functional attributes.
\end{abstract}

Key words: Cissus populnea; kunu beverage; hydrocolloids; homogeneity; natural gums; sedimentation rate

\section{Introduction}

Kunu beverage is an excellent source of carbohydrate, minerals and vitamins. Kunu a cereal based non-alcoholic fermented beverage is widely consumed in northern Nigeria. After production however, starch molecules of the cereal(s) used tend to dissociate from water in which they are held in suspension forming a two layer beverage product lacking in homogeneity. Though the consumption of kunu beverage continues to increase in Nigeria, however, the formation of sediment in the beverage is one of the major reasons some consumers reject it. Additionally, the sediment can adversely influence the quality of beverage by absorbing flavour substances. Sediment velocity relies on the particles' diameter and density, the density and viscosity of the solution. Reduction of particle size and incorporation of polysaccharide stabilizers or soluble dietary fibres are simplified means for solving the problem of beverage sedimentation.
Hydrocolloids have been used in improving cloud stability in beverage production, however, this is limited by quantity of hydrocolloids added, type of beverage product and production process adapted [1]. High quantity of hydrocolloids addition impacts adversely on texture quality of products. Hydrocolloids are important groups of polysaccharides, generally characterized by high molecular weight [2]. As food gums, they are used to improve mouth feel and to change the viscosity of solutions due to their high polymeric nature and the interactions between polymer chains when they are dissolved or dispersed [3].

Cissus populnea mucilage flour when used as soluble dietary fiber has important nutritive component for human health, due to its various physiological functions. Fresh Cissus populnea mucilage is extremely viscous giving rise to liquid products with high viscosity. Foods with high viscosity decrease protein efficacy and lipid utilization by interfering with the digestion and absorption of nutrients $[4,5,6]$. When high viscose foods are dissolved in water, they tend to slow gastric emptying [7]. Alfa et, al. reported that cissus gum has very high water-absorption and swelling capacities, becoming both pseudoplastic and thixotropic in an aqueous solution of at least $4 \% \mathrm{w} / \mathrm{v}$. As an emulsifying agent, cissus gum would perform better as an emulsion stabilizer than as emulsifying agent in comparison with gum arabic $[8,9]$. In another study, confirmed cissus gum as an emulsion stabilizer [10]. Cissus populnea(Gull and Perr) is a savannah shrub and climber which can reach height of three meters or more depending on the supporting tree and its age [11]. It is an under-utilized edible gum grown in the middle belt of Nigeria, where it has long found a place in the traditional menu of Tiv, Idoma and Igala ethnic groups $[12,13]$. It is called Ager in Tiv, Okoho in Idoma and Igala, Dafara in Hausa and Ogbolo in Yoruba languages in Nigeria [14]. The demulcent property, biocompatibility, cheapness, lack of toxicity, soothing action and non irritant nature of cissus gum favours it wide usage in several industries. In the food industry its viscose property enables it to be employed as hydrocolloid and soup thickener, its gelling/thickening property in the production of jam, jelly, marmalades, dairy products and salad dressings while its binding/coating property in the production of baked 
foods [15]. Also, there has been great interest in the medicinal application of cissus mucilage as tablet binding agent $[16,17$, 11]. This work evaluated the effect of Cissus populnea mucilage flour incorporation in beverage production on the proximate composition, functional and homogeneity properties of millet kunu.

\section{Material and Methods}

\section{Source of materials}

Fresh Cissus stems were harvested from University of Agriculture, Makurdi forest. Millet (Pinnesetum nigritarum) grains, dry sweet potato chips, malted rice and dried ginger were purchased from Wurukum market, Makurdi Local Government Area, Benue State, Nigeria. The harvested stems were packed into clean polyethylene bags and transported to the Food Preparation Laboratory, Department of Home Science and Management, University of Agriculture, Makurdi for processing.

\section{Preparation of Cissus populnea mucilage and flour}

The stems were cut to $30 \mathrm{~cm}$ long, scrapped, washed, peeled, shredded and soaked in hot distilled water (90 0C/10 min), kneaded/squeezed (10 min) and filtered (muslin cloth) to produce mucilage. The mucilage $(100 \mathrm{~g})$ was thereafter frozen (-400C, $5 \mathrm{~min}$ ), freeze dried for $48 \mathrm{hr}$ (Vacuum freeze dryer/ lyophilizer, model S020, China) while the resulting cake was milled into flour using kitchen blender (Sonik, model SB-735, Japan).

\section{Preparation of millet kunu}

Millet kunu was produced by steeping (12 hr), wet milling, gelatinizing, cooling, adding/mixing sweetener paste, portioning $(100,95,90,85,80,75 \mathrm{~g})$, adding Cissus flour $(5,10,15,20$, $25 \mathrm{~g}$ ) to $95,90,85,80,75 \mathrm{~g}$ millet kunu, respectively and stirring (wooden stirrer) to obtain millet-cissus kunu.

\section{Proximate analysis}

The moisture, crude protein, total fat, ash and crude fibre were determined according to Association of Official Analytical Chemists method, while carbohydrate was calculated by difference $[18,19]$.

\section{Functional properties}

The viscosity of the millet-cissus kunu samples were analyzed according to method, total titratable acidity according to method while $\mathrm{pH}$ was determined according to method using a $\mathrm{pH}$ meter with a glass electrode (Model 82- 63, Orion Research, Inc., Beverly, MA) $[18,20,21]$.

\section{Sedimentation characteristics}

Sedimentation rate was determined by method [22].

\section{Statistical analysis}

Data for all determinations were subjected to analysis of variance (ANOVA) while differences among means were separated using Duncan's New Multiple Range Test [23].

\section{Results}

\section{Proximate composition of millet cissus kunu}

The proximate composition revealed that millet kunu (control) had higher (91\%) moisture content than millet-cissus kunu samples (88.82 - 87.53\%), which decreased with every 5\% increase in cissus populnea flour addition (Table 1). The protein, fat, fibre, ash and carbohydrate contents of millet-cissus beverage were enhanced by $0.02-0.03 \%, 0.01-0.05 \%, 1.66-1.69 \%, 0.30$ $1.63 \%$ and $1.03-1.60 \%$, respectively with every $5 \%$ addition of cissus populnea flour. The protein, fat, fibre, ash and carbohydrate contents of millet-cissus kunu samples were higher than millet kunu, respectively.

\begin{tabular}{|c|c|c|c|c|c|c|}
\hline Samples & Moisture & Protein & Fat & Fibre & Ash & Carbohydrate \\
\hline $\mathbf{A}(100: 0)$ & $91.00 \pm 1.44 p$ & $0.25 \pm 0.01 \mathrm{~s}$ & $0.03 \pm 0.01 \mathrm{~s}$ & $0.45 \pm 0.01 \mathrm{~s}$ & $0.17 \pm 0.01 \mathrm{~s}$ & $7.12 \pm 0.01 \mathrm{~s}$ \\
\hline B $(95: 5)$ & $88.82 \pm 0.46 \mathrm{~s}$ & $0.27 \pm 0.02 \mathrm{~s}$ & $0.04 \pm 0.01 \mathrm{~s}$ & $2.11 \pm 0.01 \mathrm{p}$ & $0.47 \pm 0.03 \mathrm{~s}$ & $8.15 \pm 0.07 p$ \\
\hline C $(90: 10)$ & $88.15 \pm 0.71 \mathrm{~s}$ & $0.28 \pm 0.01 p$ & $0.05 \pm 0.01 \mathrm{~s}$ & $2.11 \pm 0.01 \mathrm{~s}$ & $0.62 \pm 0.02 \mathrm{~s}$ & $8.65 \pm 0.03 p$ \\
\hline D $(85: 15)$ & $87.89 \pm 0.55 \mathrm{~s}$ & $0.28 \pm 0.03 \mathrm{~s}$ & $0.06 \pm 0.02 \mathrm{~s}$ & $2.11 \pm 0.01 p$ & $0.85 \pm 0.01 \mathrm{~s}$ & $8.74 \pm 0.01 p$ \\
\hline $\mathbf{E}(80: 20)$ & $87.69 \pm 0.27 \mathrm{~s}$ & $0.27 \pm 0.02 \mathrm{~s}$ & $0.05 \pm 0.02 \mathrm{~s}$ & $2.11 \pm 0.01 \mathrm{p}$ & $1.01 \pm 0.01 \mathrm{~s}$ & $8.68 \pm 0.07 p$ \\
\hline $\mathbf{F}(75: 25)$ & $87.53 \pm 0.04 \mathrm{~s}$ & $0.27 \pm 0.01 \mathrm{~s}$ & $0.08 \pm 0.01 p$ & $2.24 \pm 0.01 p$ & $1.80 \pm 0.01 p$ & $8.72 \pm 0.02 p$ \\
\hline LSD & 17.7 & 0.05 & 0.01 & 0.37 & 0.72 & 1.67 \\
\hline \multicolumn{7}{|c|}{ Mean \pm SD triplicate determinations. Means with same alphabets in a column are not significantly $(P<0.05)$ different } \\
\hline \multicolumn{7}{|c|}{$\mathbf{A}(100: 0)=100 \%$ millet kunu } \\
\hline \multicolumn{7}{|c|}{ B $(95: 5)=95 \%$ millet kunu and $5 \%$ cissus flour } \\
\hline \multicolumn{7}{|c|}{ C $(90: 10)=90 \%$ millet kunu and $10 \%$ cissus flour } \\
\hline \multicolumn{7}{|c|}{ D $(85: 15)=85 \%$ millet kunu and $15 \%$ cissus flour } \\
\hline \multicolumn{7}{|c|}{ E $(80: 20)=80 \%$ millet kunu and $20 \%$ cissus flour } \\
\hline \multicolumn{7}{|c|}{$\mathbf{F}(75: 25)=75 \%$ millet kunu and $25 \%$ cissus flour } \\
\hline
\end{tabular}




\section{Functional properties of millet-cissus kunu}

The functional properties of millet-cissus kunu are presented in (Table 2). The result indicated that millet-cissus kunu with $25 \%$ cissus populnea flour addition had higher (918.53\%) viscosity value while millet kunu (control) had the least (575\%) viscosity index. The viscosity of millet-cissus kunu samples increased with increase incorporation of cissus populnea flour. Millet kunu (control) had a near neutral $\mathrm{pH}$ (6.43) value while millet-cissus kunu samples containing $20 \%$ and $25 \%$ cissus populpnea flour were more acidic $(5.55 \mathrm{pH})$. The titratable acidity of millet-cissus kunu samples however, increased (0.540 - 0.380) with every 5\% increase in cissus populnea flour.

\begin{tabular}{|c|c|c|c|}
\hline Samples & Viscosity (\%) & pH & Titratable acidity $(\mathrm{g} / \mathrm{ml})$ \\
\hline $\mathbf{A}(100: 0)$ & $575.00 \pm 35.36 \mathrm{~s}$ & $6.43 \pm 0.03 p$ & $0.540 \pm 0.005 \mathrm{~s}$ \\
\hline B $(95: 5)$ & $620.82 \pm 28.28 \mathrm{~s}$ & $5.49 \pm 0.01 \mathrm{~s}$ & $0.530 \pm 0.005 \mathrm{~s}$ \\
\hline C $(90: 10)$ & $675.15 \pm 7.07 \mathrm{~s}$ & $5.49 \pm 0.01 \mathrm{~s}$ & $0.440 \pm 0.005 p$ \\
\hline D $(85: 15)$ & $773.89 \pm 4.24 \mathrm{~s}$ & $5.53 \pm 0.01 \mathrm{~s}$ & $0.410 \pm 0.005 p$ \\
\hline $\mathbf{E}(80: 20)$ & $840.69 \pm 56.57 \mathrm{~s}$ & $5.55 \pm 0.02 \mathrm{~s}$ & $0.380 \pm 0.005 \mathrm{~s}$ \\
\hline $\mathbf{F}(75: 25)$ & $918.53 \pm 25.45 \mathrm{~s}$ & $5.55 \pm 0.01 \mathrm{~s}$ & $0.390 \pm 0.005 \mathrm{~s}$ \\
\hline LSD & 146.7 & 1.13 & 0.09 \\
\hline \multicolumn{4}{|c|}{ A $(100: 0)=100 \%$ millet kunu } \\
\hline \multicolumn{4}{|c|}{ B $(95: 5)=95 \%$ millet kunu and $5 \%$ cissus flour } \\
\hline \multicolumn{4}{|c|}{ C $(90: 10)=90 \%$ millet kunu and $10 \%$ cissus flour } \\
\hline \multicolumn{4}{|c|}{ D $(85: 15)=85 \%$ millet kunu and $15 \%$ cissus flour } \\
\hline \multicolumn{4}{|c|}{ E $(80: 20)=80 \%$ millet kunu and $20 \%$ cissus flour } \\
\hline \multicolumn{4}{|c|}{$\mathbf{F}(75: 25)=75 \%$ millet kunu and $25 \%$ cissus flour } \\
\hline
\end{tabular}

\section{Sedimentation characteristics of millet-cissus kunu}

The sedimentation characteristics of millet-cissus kunu samples in the first $4 \mathrm{hr}$ of storage at ambient temperature are presented in Figure 1. The sedimentation rates indicate that millet-cissus kunu with 20\% cissus populneamucilage flour had highest colloidal properties exhibiting no dissociation of starch granules in the first $1.5 \mathrm{hr}$ of storage at ambient temperature, with a $1-3 \mathrm{ml}$ dissociation of starch granules in the remaining $2.5 \mathrm{hr}$ of the first $4 \mathrm{hr}$ storage period. It was followed by sample 75:25 with starch granules dissociation values of $0,0,1,2,2,4$, 4 and $4 \mathrm{ml}$ at $0.5,1,1.5,2,2.5,3,3.5$ and $4 \mathrm{hr}$, respectively. The control (100\% millet kunu) had the highest rate of starch granule dissociation 0 ( $0.5 \mathrm{hr}), 2 \mathrm{ml}(1 \mathrm{hr}), 2 \mathrm{ml}(1.5 \mathrm{hr}), 2 \mathrm{ml}(2 \mathrm{hr}), 4 \mathrm{ml}$ ( $2.5 \mathrm{hr}), 6 \mathrm{ml}(3 \mathrm{hr}), 7 \mathrm{ml}(3.5 \mathrm{hr}$ ) and $7 \mathrm{ml}(4 \mathrm{hr})$ on storage than all the millet-cissus kunu samples. Cissus populnea flour granules have exhibited binding properties on millet starch granules in suspension, thereby slowing down the rate of sedimentation of starch granules in kunu beverage. In the last $4 \mathrm{hr}$ of storage, millet-cissus kunu with $25 \%$ cissus populnea flour addition had sedimentation rates of $2 \mathrm{ml}, 2 \mathrm{ml}, 4 \mathrm{ml}, 6 \mathrm{ml}, 7 \mathrm{ml}$ and $8 \mathrm{ml}$ at $5.5 \mathrm{hr}, 6 \mathrm{hr}, 6.5 \mathrm{hr}, 7 \mathrm{hr}, 7.5 \mathrm{hr}$ and $8 \mathrm{hr}$, respectively. Millet-cissus kunu with $10 \%$ cissus flour addition had the highest rate of sedimentation in the last $4 \mathrm{hr}$ of storage, with 2, 4, 6, 12, 15, 18 and $19 \mathrm{ml}$ of the starch granules had settled from the solution at 5, 5.5, 6.0, 6.5, 7, 7.5 and $8 \mathrm{hr}$, respectively. The $100 \%$ millet kunu (control) exhibited a slower rate of sedimentation with 1 , $2,4,5,6,7,7$ and $8 \mathrm{ml}$ of the starch granules settling out from the solution at $4.5,5,5.5,6,6.5,7,7.5$ and $8 \mathrm{hr}$ of storage at ambient temperature.

\section{Discussion}

Kunu like other beverages are higher in moisture content than any other parameter. This may be linked to the use of kunu principally for thirst quenching and refreshing purposes. Also, the climate of the zone where kunu is produced and consumed most predominantly calls for this. The dry season which coincide with the peak of production are particularly characterized by very hot weather and excessive loss of fluid. No significant difference was observed in the moisture content of millet-cissus kunu samples while millet kunu (control) had significantly $(\mathrm{P} \leq 0.05)$ higher moisture content than all the millet-cissus kunu samples. The differences in moisture content (2.18-3.47\%) may be due to the high water absorption capacity of cissus populnea mucilage flour. The moisture content of millet-cissus kunu samples conform to earlier findings by [24].

There was no significant statistical difference $(\mathrm{P}<0.05)$ between the protein content of millet-cissus kunu samples and control. All the kunu samples were generally low in protein content. The protein content of this study was in contrast with earlier findings of $[24,25]$. The protein content of millet-cissus kunu has made it to be more nutritious than any of the carbonated soft drinks sold in Nigeria, that are devoid of protein but high in sugar, colouring and carbonated water content. 
Fat content of millet-cissus kunu was found to increase with every 5\% cissus populnea mucilage flour addition. The low fat content of both control and millet-cissus kunu samples were in conformity with the report of [24]. This could be attributed to the low fats (1-2\%) content of cereals generally as earlier documented by [26]. The low fat content of millet-cissus kunu is an indication that cissus populnea mucilage flour is a poor source of fat.

There was great increase in the amount of fibre in each sample of millet-cissus kunu relative to control. This could be attributed to addition of the mucilage flour after filtration of millet kunu. This was in conformity with findings that cissus gum has very high water-absorption and swelling capacities, which makes them become both pseudoplastic and thixotropic in aqueous solution [8]. The high fibre content of millet-cissus kunu could be employed in the prevention/management/treatment of type 2 diabetes, hypercholesterolemia and body weight in humans.

The high ash content of the millet-cissus kunu samples is an indication that the mucilage flour is a rich source of mineral elements. The processing technique employed has a direct effect on the ash content. Products whose processing method does not require filtration tend to be higher in ash content. On the other hand, among those filtered before consumption, variation in pore size of the sieving material is the determinant factor. Sieving materials with larger pore sizes have higher quantity of suspended particles hence higher ash content.

The carbohydrate contents were relatively low and may be attributed to filtration of millet kunu before addition of cissus mucilage flour. The high fibre content of the kunu samples could account for their low carbohydrate content. The carbohydrate content of this study contrasted the findings of [27].

It was observed that the $\mathrm{pH}$ of millet-cissus kunu samples decreased with increase in cissus populnea flour addition relative to control and conforms with the earlier findings by that kunu is an acidic food [28]. The kunu samples were 'slightly acidic with $\mathrm{pH}$ (5.49 - 5.55) values for millet-cissus kunu and 6.43 for control. The low $\mathrm{pH}$ values (5.49 - 5.55)/acidity were due to slight fermentation during processing or addition of species of low acidic value for a sour taste. Adebayo et, al. had reported that the presence of lactobacillus, Acidophillus, Candida species and Saccharomyces cerevisiae bacteria which help in acid fermentation of kunu account for their acidity [25]. These bacteria however, have been reported to be non-pathogenic as they are beneficial to humans [25]. Products with low $\mathrm{pH}$ values have higher titratable acidity content and vice versa. Unfermented products tend to have higher values of $\mathrm{pH}$ tending towards the neutral state.

The values of titratable acid in all the millet-cissus mucilage flour substituted kunu samples were statistically similar $(\mathrm{P}<0.05)$ but lower than $3.30-3.40 \mathrm{~g} / \mathrm{ml}$ and $2.18-2.26 \mathrm{~g} / \mathrm{ml}$ reported by $[28,29,26]$. The titratable acid values of millet-cissus kunu were however, higher than $0.4608-0.3870 \mathrm{ml} / \mathrm{min}$ reported by [30] The low value of TTA for millet-cissus kunu samples indicates poor fermentation with increased incorporation of cissus mucilage flour, which could have caused poor production of lactic acid. This invariably led to increase in their $\mathrm{pH}$ values.

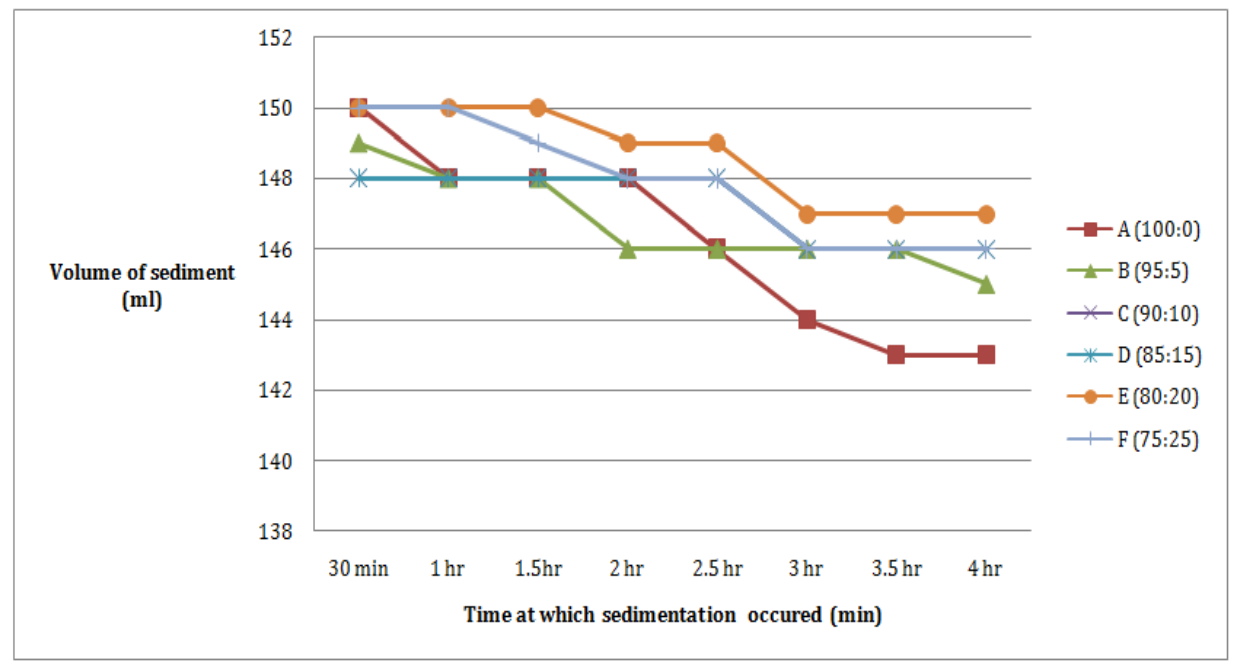

Figure 1: Sedimentation rates of millet-cissus kunu during $4 \mathrm{hr}$ storage at ambient temperature Key

A $(100: 0)=100 \%$ millet kunu

B $(95: 5)=95 \%$ millet kunu and $5 \%$ cissus flour

C $(90: 10)=90 \%$ millet kunu and $10 \%$ cissus flour

D $(85: 15)=85 \%$ millet kunu and $15 \%$ cissus flour

E $(80: 20)=80 \%$ millet kunu and $20 \%$ cissus flour

$\mathrm{F}(75: 25)=75 \%$ millet kunu and $25 \%$ cissus flour 
The values of the sedimentation rate (Figure 1 and 2) showed decrease in the sedimentation rates of millet-cissus kunu samples with increase in Cissus populnea mucilage flour incorporation. Abel et, al. had observed that, interactions between particles in a solution modify the settling behavior of a given particle, relative to that of an isolated particle. Abel and co-workers stated that the most significant interactions being hindered settling, clustering and diffusion [31]. In this study however, the predominant interaction observed was hindered settling, as addition of cissus mucilage flour may have decreased the sedimentation velocity of sorghum particles that were held in suspension in the heterogenous solution. That is, as the volume fraction of cissus flour is increased, the average separation distance between each particle of sorghum is decreased. Hydrodynamic interactions are quite strong at these short separation distances, and thus may retard the motion of sorghum starch particles. Sedimentation rate is therefore decreased. This was in contrast with the earlier findings of [30]. Among the samples made with Cissus populnea mucilage flour, sample 95:5 had the highest sedimentation rate at the end of $8 \mathrm{hr}$ of storage while the lowest rate was that of 80:20. This affirmed the hindered settling effect of cissus mucilage flour on sorghum starch particles in millet-cissus kunu beverage.

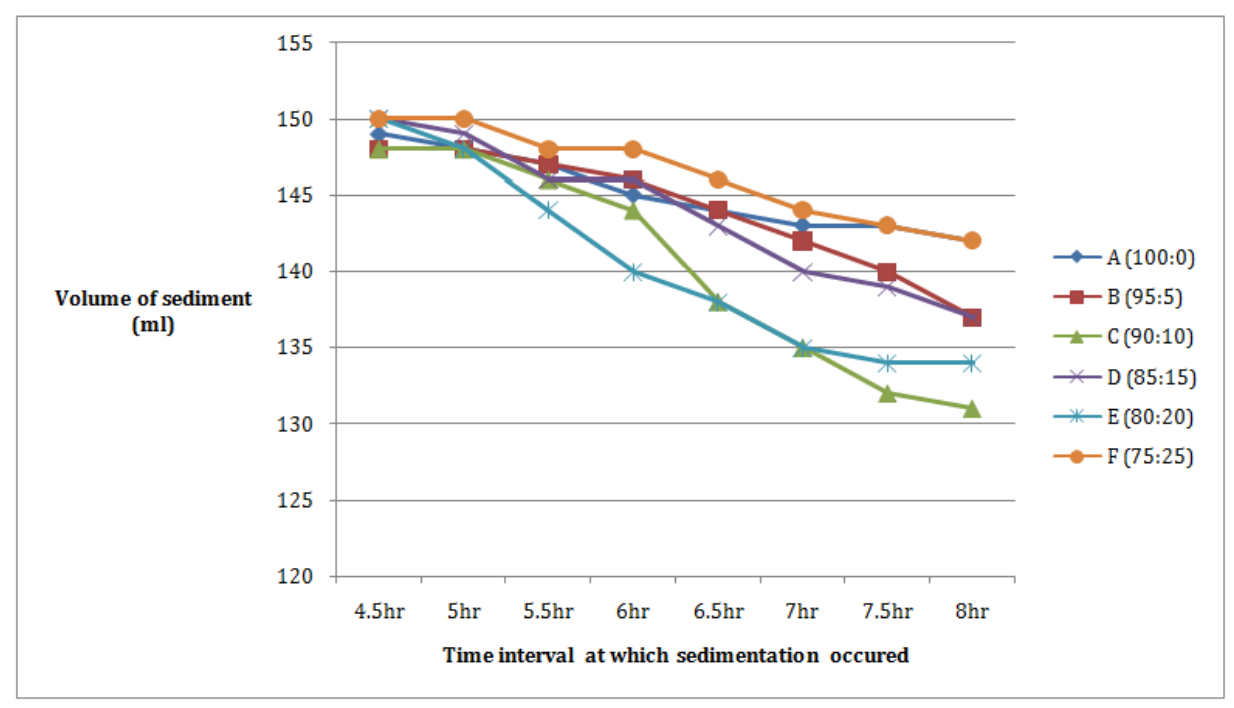

Figure 2: Sedimentation rates of millet-cissus kunu during $8 \mathrm{hr}$ storage at ambient temperature

Key

A $(100: 0)=100 \%$ millet kunu

B (95:5) $=95 \%$ millet kunu and $5 \%$ cissus flour

C $(90: 10)=90 \%$ millet kunu and $10 \%$ cissus flour

$\mathrm{D}(85: 15)=85 \%$ millet kunu and $15 \%$ cissus flour

E $(80: 20)=80 \%$ millet kunu and $20 \%$ cissus flour

$\mathrm{F}(75: 25)=75 \%$ millet kunu and $25 \%$ cissus flour

\section{Conclusion}

The incorporation of cissus populnea mucilage flour in millet kunu production improved its proximate composition and functional properties but lowered the rate of sedimentation of this beverage. The production of cissus populnea mucilage flour should be exploited to enhance its utilization in the beverage industry.

\section{Acknowledgement}

The authors most sincerely appreciate the staff of International Institute for Tropical Agriculture (IITA) Ibadan, Oyo State, Nigeria for assisting with the dehydration of the mucilage.

\section{Declaration}

The authors declare that there is no conflict of interest.

\section{References}

1. Sinchaipanit P, Kerr W L. Effect of reducing pulp-particles on the physical properties of carrot juice. ASEAN Food Journal. 2007; 14(3):205-214.

2. Sahraiyan B, Naghipour F, Karimi M, Davoodi MG. Evaluation of Lepidium sativum seed and guar gum to improve dough rheology and quality parameters in composite rice-wheat bread. Food Hydrocolloids. 2013;30(2):698-703.

3. Yaseen EI, Herald TJ, Aramouni FM, Alavi S. Rheological properties of selected gum solutions. Food Research International. 2005; 38(2):111-119.

4. Poksay KS, Schneeman BO. Pancreatic and intestinal response to dietary guar gum in rats. J Nutr. 1983;113(8):1544-1549.

5. Simons LA, Gayst S, Balasubramaniam S, Ruys J. Long-term treatment of hypercholesterolaemia with a new palatable formulation of guar gum. Atherosclerosis. 1982;45(1):101-108. 
6. Ikegami S, Tsuchihashi F, Harada H, Tsuchihashi N, Nishide E, Innami S. Effect of viscous indigestible polysaccharides on pancreatic-biliary secretion and digestive organs in rats. J Nutr. 1990;120(4):353-360.

7. Shah N, Mahoney RR, Pellett PL. Effect of guar gum, lignin and pectin on proteolytic enzyme levels in the gastrointestinal tract of the rat: a time-based study. J Nutr. 1986;116(5):786-794.

8. Alfa J, Chukwu A, Udeala OK. Cissus stem gum as potential dispersant in pharmaceutical liquid systems: emulsifying and suspending properties. Boll Chim Farm. 2001;140(2):68-75.

9. Balami AH, Bangudu AB. Evaluation of Cissus populnea bark gum as an emulsifying agent in Nigeria: Proceedings of second National Science Conference NAAP 1992.

10. Alfa J, Chukwu A, Udeala OK. Cissus stem gum as potential dispersant in pharmaceutical liquid systems: rheological characterization. Boll Chim Farm. 2001;140(1):20-27.

11. Ibrahim H, Rai PP, Bangudu AB. Evaluation of mucilage from the bark of Cissus populnea. African Journal of Pharmaceutical Science. 1992; 22:35-41.

12. Adebowale KO, Nwokocha LM, Agbaje WB. Composition and food value of leaves of two tropical food thickeners-bombax costatum and cissus populnea. Canadian Journal of Pure and Applied Sciences. 2015;9(1):3221-3227.

13. Adebowale KO, Nwokocha LM, Agbaje WB. Composition of Cissus populnea stem. Journal of Food Composition and Analysis. 2013; 30(1):41-46.

14. Iwe MO, Obaje PO, Akpapunam MA. Physicochemical properties of Cissus gum powder extracted with the aid of edible starches. Plant Foods Hum Nutr. 2004;59(4):161-168.

15. Owuno F, Eke-Ejiofor J, Wordu G. Effects of cissus (Cissus populnea) gum on dough rheology and quality of wheat-cassava composite bread Journal of Food, Agriculture and Environment. 2012;10(2):80-84.

16. Eichie FE, Amalime AE. Evaluation of the binder effects of the gum mucilage's of Cissus populea and Acasia senegal on the mechanical properties of paracetamol tablets. African Journal of Biotechnology. 2007;6(19):2208-2211.

17. Ibrahim MA, Dawes VN. Formulation of once - and twice - daily theophyllin matrix tablets using Cissus populnea Polymer. African Journal of Biotechnology. 2000; 62(3):243-247.

18. AOAC. Association of Official Analytical Chemist. Official Method of Analysis of Official Analytical Chemist, 2005 Washington DC.
19. Egan H, Kirk RS, Sawyer R. Pearson's Chemical Analysis of Foods. 8th Edition, Churchill Livingstone, London, UK. 1981; 15-18.

20. Onwuka G. Food analysis and instrumentation: theory and practice. Naphthalic prints, Surulere, Lagos, Nigeria. 2005; 219-230.

21. Afoakwa EO, Budu AS, Merson AB. Application of response surface methodology for optimizing the pre-processing conditions of Bambara groundnut (Voandzei subterranea) during canning. International Journal of Food Engineering. 2006;2(5):1-8.

22. Larmond E. Laboratory methods for sensory evaluation of food, Ottawa Agriculture, Canada. 1997;73.

23. Duncan D B. Multiple range and multiple F tests. Biometrics. 1955; 11:1-42.

24. Gaffa T, Jideani IA, Nkama I. Nutritional composition of different types of kunu produced in Bauchi and Gombe States of Nigeria. International Journal of Food Properties. 2001; 5(2):351-357.

25. Adebayo GB, Otunola GA, Ajao TA. Physicochemical, Microbiological and Sensory Characteristics of Kunu Prepared from Millet, Maize and Guinea Corn and Stored at Selected Temperatures. Advance Journal of Food Science and Technology. 2010;2(1):41-46.

26. McDonald P, Edwards RA, Greenhalgh JFD. Animal Nutrition; 2nd Edn.; Longman Publishers, London. 1977; 1246.

27. Lawal AI, Babalola KA, Ajibola GO, Olatoye KK. Influence of sprouted Africa breadfruit milk extract on nutritional, sensory and microbiological quality of kunun-zaki. Annals of Food Science and Technology. 2016;17(1):132-138.

28. Onuorah SI, Adesiyun AA, Adekeye JO. Occurance of Staphylococci and Colifornis in kunun zaki and utensils used in its preparation in Samaru, Zaria. Journal of Food Agriculture. 1987;1:31-34.

29. Makinde F, Oyeleke O. Effect of sesame seed addition on the chemical and sensory qualities of sorghum based kunun-zaki drink. African Journal of Food Science and Technology. 2012;3(9):204-212.

30. Bede EN, Okeke CE, Amandikwa C. Physicochemical Properties and Sensory Evaluation of Kunu-Zaki Beverage Produced by Substitution of Sweet Potatoes with Date Fruits. Journal of Environmental Science, Toxicology and Food Technology. 2015; 9(3):81-84.

31. Abel JS, Stangle GC, Schilling CH, Aksay IA. Sedimentation in flocculating colloidal suspensions. Journal of Materials Research. 1994; 9(2):451-461. 